\title{
Shredders are abundant and species-rich in tropical continental-island low-order streams: Gorgona Island, Tropical Eastern Pacific, Colombia
}

\author{
Magnolia Longo ${ }^{1 *} \&$ Juan F. Blanco ${ }^{1}$ \\ 1. Instituto de Biología, Facultad de Ciencias Exactas y Naturales, Universidad de Antioquia, Medellín, Colombia; \\ mc_longo@hotmail.com, blanco@matematicas.udea.edu.co
}

Recibido 18-X-2013. Corregido 20-XI-2013. Aceptado 19-XII-2013.

\begin{abstract}
Macroinvertebrate shredders may have been overlooked in tropical streams due to the geographical bias of early studies, methodological limitations, and the complex influences of local-scale factors. While shredders seem to be scarce in most oceanic island streams, we here test if they are abundant in a continental island. Gut content analyses of benthic macroinvertebrates were used to identify shredding taxa in streams located in different types of forest in Gorgona Island (Tropical Eastern Pacific). General dietary overlap (GO) was quantified and relative biomass, relative frequency and the leaf litter percentage in the guts were used to establish the relative importance of each taxon in the shredding guild. Various indices were used to identify the spatial arrangement (i.e. contagious or random) of each taxon and shredding guild among streams. We identified 31 shredding taxa that were divided into specialist-shredders (14 taxa), generalist-shredders (10), and collector-shredders (7). There was a complete $G O(0.75, p<0.001)$ for the guild. Cockroaches (Epilampra) were the most represented shredders due to the greatest contribution to guild total biomass and to the highest content of leaf litter in their guts. These organisms were more important than shrimps and crabs in terms of abundance and biomass in leaf pack samples. Potimirin shrimps ranked second and Stenochironomus midges ranked third. Among aquatic insects, other secondarily important species were Leptohyphes (Ephemeroptera), Macrelmis, Anchytarsus and Tetraglosa (Coleoptera). Ten taxa exhibited contagious spatial pattern and twenty-one exhibited a random distribution. Resource distribution (i.e., leaf packs) between streams was random too. The guild was contagiously distributed, but this result could be highly influenced by the taxa with contagious distribution. Mean abundance, richness and mean biomass of shredders were not significantly correlated with any of the environmental variables measured. Three factors seemly explain the high richness and abundance of shredders in Gorgona Island: (1) its continental origin, (2) its current proximity to the continent ( $35 \mathrm{~km})$, and (3) the high diversity and availability of leaf litter and woody debris inputs to the streams. Although crabs, shrimps, aquatic insects and semiaquatic-cockroaches coexisted in Gorgona Island, the latter were the most important leaf litter shredders in terms of biomass. Rev. Biol. Trop. 62 (Suppl. 1): 85-105. Epub 2014 February 01.
\end{abstract}

Key words: shredders, leaf litter, dietary overlap, spatial arrangement.

The available studies reveal that richness, abundance and biomass of shredder macroinvertebrates are lower in streams located in oceanic islands than in continents (Benstead, March, Pringle, Ewel \& Short, 2009). In addition, prior to the studies by Boyero et al., (2011a, b), tropical streams were regarded as species-poor in terms of shredder taxa compared to temperate counterparts because of the overrepresentation of oceanic islands in stream ecology studies (e.g. Puerto Rico,
Society Islands of French Polynesia, Hawaiian Islands). Macroinvertebrate communities in oceanic islands are structurally simple, due to the bottleneck imposed by isolation to aquatic insects (Smith, Covich \& Brasher, 2003; Covich 2006a). In the remote islands in the Pacific region, these communities are dominated by diadromous decapods and molluscs, and only a few groups of Diptera and Odonata are present (e.g. Resh, Barnes \& Craig., 1990; Marquet, 1991; Choy, 1991; Fossati, Vallier \& Mosseron, 
1998; Fossati, Mosseron \& Keith, 2002; Craig, 2003; March, Benstead, Pringle \& Luckymis, 2003; Benbow, Mcintosh, Burky \& Way, 2005; Benstead et al., 2009). As another example, Plecoptera and Megaloptera are absent in Puerto Rico (Caribbean) due to biogeographic processes (Ramírez \& Hernández-Cruz, 2004). Accordingly the shredder guild is dominated by shrimps, crabs and snails (e.g. Ramírez \& Pringle, 1998; Crowl, McDowell, Covich \& Johnson, 2001). The shredder insect guild is dominated by a few species of Leptoceridae and Calamoceratidae (Trichoptera), and Tipulidae (Diptera) with low densities and biomass (Yule, 1996a; 1996b). Therefore, the paucity of shredder species in tropical oceanic islands has biased the hypothesis of the scarcity of shredders in the tropics (Wantzen, Yule, Mathooko \& Prigle, 2008; Boyero et al., 2011a; b). Continental islands, however, seem to exhibit a high richness of aquatic and semiaquatic insects that coexist with diadromous fauna (Bass, 2003; Longo-Sánchez \& Blanco, 2009; Li \& Dudgeon, 2008; Yam \& Dudgeon, 2005), but studies on continental-volcanic islands are still scant [(e.g. Yule 1996a; 1996b): Bougainville, Papua New Guinea; Boyero \& Bailey (2001): Coiba, Panamá; Gómez-Aguirre, Longo-Sánchez \& Blanco (2009); Longo, GómezAguirre, Blanco \& Zamora-González (2009): Gorgona, Colombia].

Since the breakdown of coarse organic matter is a key ecosystem process in streams (Cummins, 1973), it is important to identify the shredding taxa for understanding foodweb structure and ecosystem function (Dangles \& Malmqvist, 2004). In the Tropics, in general, such studies are still insufficient because shredder insect composition and the life histories of each taxon are poorly known (e.g. Dudgeon, 1994; Ramírez \& Pringle, 1998; Tomanova, Goitia \& Helešic, 2006; Yule et al., 2009; Cheshire, Boyero \& Pearson, 2005; Li \& Dudgeon, 2008; Camacho, Boyero, Cornejo, Ibáñez \& Pearson, 2009; Chará-Serna, Chará, Zúñiga, Pedraza \& Giraldo, 2010; Boyero et al., 2011a; b). In one of the few studies conducted in tropical island streams, (Yule, 1996a; 1996b) found in Bougainville Island (70-80\% shaded), 10 shredder taxa (out of 48 species), including 2 crustaceans and 8 insects. The abundance was low, and it was associated with low levels of leaf packs in streams (owing to the persistently high rainfall). In another study, Li \& Dudgeon (2008) reported a low richness of shredders in both shaded (4 taxa out of 58) and unshaded streams (2) in Lantau Island and New Territories of Hong Kong. Benstead et al. (2009) found a total lack of insect shredders, and a minor role assumed by macroconsumer decapods and gastropods in a Micronesia stream, and it was attributed to the extreme isolation experienced by mid-Pacific island streams, placing them at the lowest end of shredder biodiversity and biomass, thus restricting the ecosystem function (i.e. decomposition) of their species-poor communities.

Quests for shredding macroinvertebrates in tropical streams have been poorly replicated, a major drawback for identifying the actual patterns of richness, due to the great stream to stream variability (Camacho et al., 2009). Thus, it is necessary to replicate samples among streams and habitats at a regional scale. This is particularly critical because the spatial arrangement of shredders among island streams is expected to be contagious, similarly to the patchy arrangement of most biota, their resources, and their habitats in streams (e.g. Pringle et al., 1988; Downes, Lake \& Schreiber, 1993). Bearing in mind the ecological importance of the shredder guild and the limited replication in most studies, researchers from different countries joined efforts in global-scale studies to understand their biology and ecology (Wantzen \& Wagner, 2006; Boyero et al., 2009; 2011a; b). For instance, one of these studies provided insights on the potential impact of global warming on rise of local extinction rates of shredders, thus affecting their role (Boyero et al., 2011a). Nonetheless, this study was conducted solely on continental streams, while island streams were overlooked, despite they have been classified as highly vulnerable to episodic and global changes such as hurricanes, floods, droughts (Covich, Crowl 
\& Heartsill-Scalley, 2006), sea level rise, biological invasions and pollution (Chown, Lee \& Shaw, 2008), and despite extinctions are not likely to be offset by colonization by new species due to isolation.

We studied the composition and spatial arrangement of shredder macroinvertebrates in Gorgona Island streams, located in the Colombian Tropical Eastern Pacific. This island ecologically and climatically unique in the region due to the volcanic and continental origins, location in the region Choco Biogeographic (a biodiversity hotspot), and preserved condition (Natural National Park). Other characteristics such as aseasonal rainfall, basalt and sedimentary geology, primary and secondary forests and low-intensity human activities, place Gorgona Island as a key site for ecological studies in streams. As well, Gorgona Island streams are pristine-mountain $\left(1^{\text {st }}\right.$ and $2^{\text {nd }}$ order $)$, located at low elevations $(0-300 \mathrm{~m})$, and their landscape resembles low-order and steep-gradient temperate streams, where the allochthonous resource supply is greater than the autochthonous production.

Previous studies in Gorgona Island streams revealed that stream insect richness is high compared with that found in other tropical Pacific islands, and should, therefore, considered a biodiversity hotspot for this group (Gómez-Aguirre et al., 2009; Longo-Sánchez et al., 2009). In this study, we asked the following questions: (1) Are shredder taxa scarce in terms of abundance and poor in terms of species?; (2) Does stream location in primary or secondary forests affect the richness and abundance of shredders?; (3) What is the spatial arrangement pattern of each taxon and of the guild (random or contagious) at the island-scale?; (4) What are the most important taxa of this guild (based on relative biomass and frequency of occurrence and content of leaf litter tissue in guts), and what is the extent of the trophic niche overlap among shredders? If Gorgona Island streams differ in terms of the type of riparian forest and instream stock of leaf litter abundance and richness, we predict that shredders will show a proportional response in terms of abundance and richness, they will be more abundant and taxon rich in streams with native riparian vegetation. The spatial arrangement of each taxon and the entire guild among streams will be contagious. We also predict that the shrimps will have higher relative importance because their biomass and abundance exceed that of insects as observed in other islands. Trophic niche overlap will be high among shrimps and low among aquatic insects. To test these hypotheses, the objectives of this work are: (a) to identify the shredder taxa based on the examination of gut contents; (b) to examine the local variation of estimates of guild (total abundance, total richness and total biomass); (c) to identify the type of spatial distribution for each taxon and for the entire guild; and (d) to establish the importance value of each taxon (e.g. insects, shrimps and crabs) of the guild (e) to analyze the trophic niche overlap.

\section{MATERIAL AND METHODS}

Study area. Gorgona Island $\left(16 \mathrm{~km}^{2}\right)$ is located on the continental shelf, $35 \mathrm{~km}$ off the Pacific coast of Colombia (Fig. 1). This island is located in the Chocó Biogeographic region. This region is one of the world's rainiest $\left(>6000 \mathrm{~mm} \mathrm{yr}^{-1}\right)$, and it exhibits one of the largest coastal tropical rainforest remnants on Earth (Rangel \& Arellano, 2004). This region is also an important biodiversity hotspot (Myers, Mittermeier, Mittermeier, Da Fonseca \& Kent, 2000). Gorgona was operated as a penitentiary island between 1960 and 1982, but it was declared Natural National Park in 1983. Rocks are ultramafic, elevation ranges from 0 to 330 masl, average air temperature is $26^{\circ} \mathrm{C}$, and mean total annual rainfall is $6661 \mathrm{~mm}$, thus feeding a great number of permanent and ephemeral streams. A detailed account of hydroclimatology is found in Blanco (2009).

Study streams. Three streams were selected from each of the island's slopes: East (Ilú, Iguapoga, and Pizarro) and West (Playa Verde, La Camaronera and Cocal Norte) (Fig. 1). These have different type of forest cover: 1) 


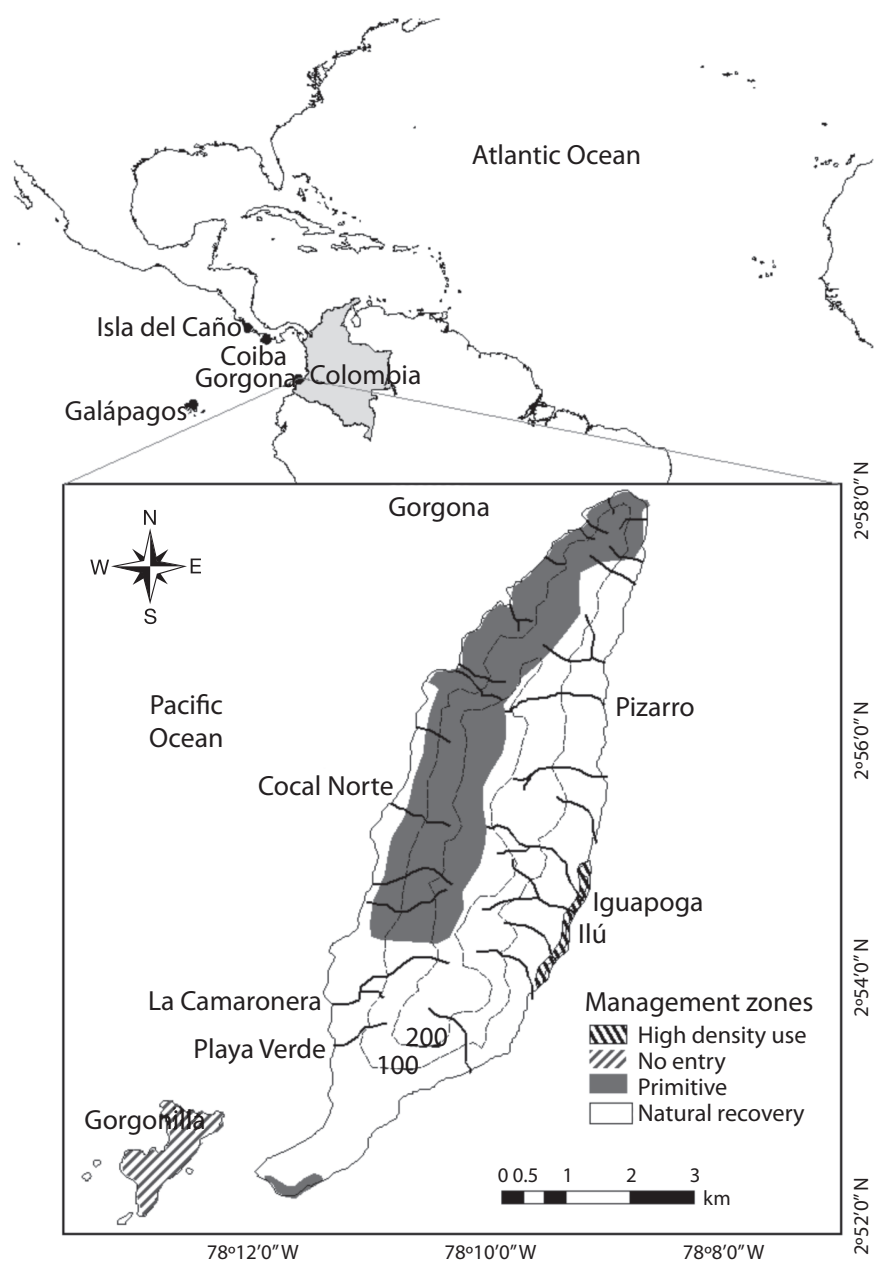

Fig. 1. Study streams in Gorgona Island (Colombian Tropical Pacific). Forest management zones are indicated.

native, 2) introduced, and 3) secondary forest (Table 1, Fig. 1). In general, all streams exhibited short and low order $\left(1^{\text {st }}-2^{\text {nd }}\right)$ courses, with nearly straight reaches in the headwaters and meandering reaches in the lowland. Records of some physical, chemical and biological variables are presented in Table 1. Landslides, bank failures, and fallen trees commonly occurred along all streams due to the high annual rainfall rate. Prior to the designation of the Natural National Park, lowhead-dams for hydropower were constructed and fruit-tree plantations were established in Ilú, Iguapoga and Pizarro. In contrast, Playa Verde, La Camaronera and
Cocal Norte, located on the opposite island's slope, did not exhibit visible signs of human disturbance during the penitentiary period. Information about the island's tropical rainforest flora (Rangel, 1990) and spatio-temporal patterns of leaf litter composition in selected streams (Valencia, Pérez, Lizarazo \& Blanco, 2009) is available. Detailed information about stream macroinvertebrate distribution was also recently published (Gómez-Aguirre et al., 2009; Longo-Sánchez et al., 2009).

Sampling and leaf litter processing. Two samplings were conducted (February and 


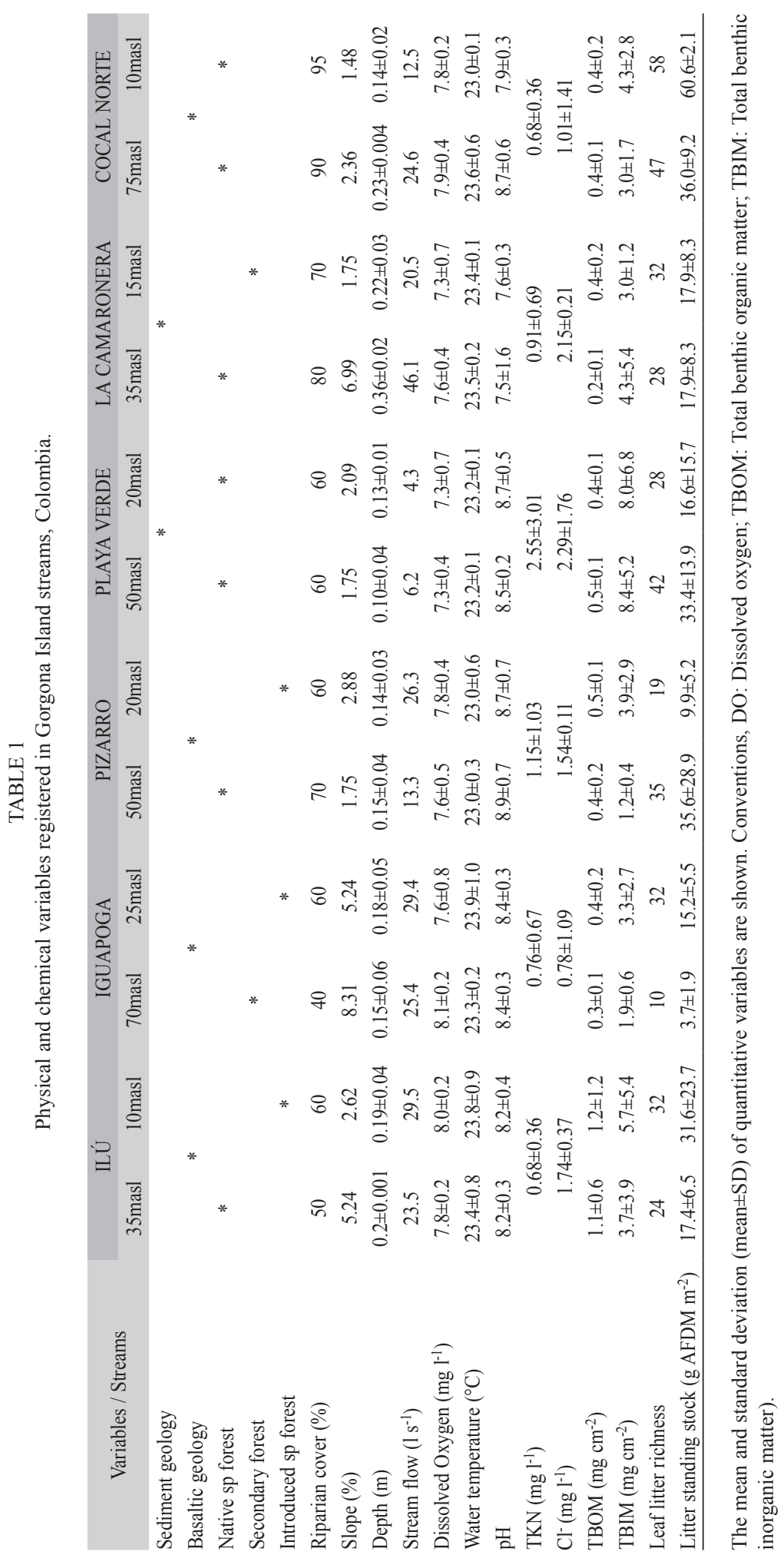


March, 2009) in the six study streams. These months corresponded to the low rainfall period. Some variables describing each stream are shown in Table 3. Sampling was conducted on two reaches (30m in length each one) in each stream, they were located in lowlands and steeper parts (range: 10-70masl). These were selected according to access. Physical and chemical variables were measured in the field (4 repetitions for each measurement in each reach for each sampling) with standard instruments [temperature and dissolved oxygen (handylab Ox 12, SCHOTT Instruments, Mainz, Germany), pH (ECO10 pH, SCHOTT Instruments, Mainz, Germany), and flow (FP101-FP201 Global Flow Probe, Gold River CA, USA)]; water samples were collected for measuring total nitrogen (Kjeldahl method), and chloride (ion chromatography) in laboratory. Geology (basaltic and sedimentary), forest type (native, secondary and exotic species plantation), riparian cover percent (estimated visually in the field), slope (Suunto PM-5 clinometer, Valimotie, Finland), and depth (wooden folding ruler) were measured too; cobble (4 units) surfaces were randomly selected from each reach of each stream and scraped (area $23.76 \mathrm{~cm}^{2}$ on each cobble), to measure total benthic organic matter (TBOM) and total benthic inorganic matter (TBIM) in laboratory following methods by Eaton, Clesceri \& Greenberg (1995). Submerged leaf litter packs were manually-collected following a zigzag path over a $10 \mathrm{~m}$ upstream distance during 10min. Samples collected were placed into plastic bags and preserved in $90 \%$ alcohol (to stop the digestive process in the macroinvertebrates). Macroinvertebrates were separated from the litter within the next $24 \mathrm{~h}$ in the Gorgona Natural National Park field station and preserved in vials with $70 \%$ alcohol. All samples were pooled into a single sample per reach. The leaf litter was bagged and transported to the laboratory in Universidad de Antioquia. Samples were oven-dried to a constant mass at $80^{\circ} \mathrm{C}$ for $72 \mathrm{~h}$, and then weighed. Leaves were classified into genus, family or morphotype to estimate leaf richness as described by Valencia et al. (2009). Quantification of litter standing stocks was performed by randomly placing five $\left(0.25 \mathrm{~m}^{2}\right)$ quadrats along the sampling reach. Leaf and woody litter were bagged and transported to the laboratory for oven-drying.

\section{Laboratory procedures for macroinver-} tebrates. Individuals were identified primarily to genus-level using identification keys by Roldán (1988), Aristizábal-García (2002), Pérez-Gutiérrez (unpubl. data), Domínguez \& Fernández (2009), and Wiggins (1996). Stenochironomus and Tanypodinae were the unique taxa identified of the Chironomidae family, the rest of individuals were identified to family level; Hydrophiloidea individuals were identified only to family level. Many taxa were confirmed by experts, and the organisms were deposited in the reference collection of benthic macroinvertebrates of the Limnology Laboratory at the Universidad de Antioquia (CLUA35). All individuals were grouped by taxon and counted. At least 10 individuals of each taxon were oven-dried at $60^{\circ} \mathrm{C}$ for $24 \mathrm{~h}$ and then weighed to the nearest $0.00001 \mathrm{~g}$ (analytical balance Sartorius Basic 0.00001).

Between two and ten individuals per taxon and stream were ventrally-dissected (Peckarsky, 1996). Their guts were extracted under a dissecting microscope and analyzed under a microscope (at a 200X magnification). The smallest chironomids were whole-mounted on glass slides. Gut contents were mounted on glass slides adding a glycerine drop. Food items were classified as follows, according to Cheshire et al., (2005): Fine Particulate Organic Matter (FPOM, particles $<50 \mu \mathrm{m}$ ), Coarse Particulate Organic Matter (CPOM, size range: $50 \mu \mathrm{m}-1 \mathrm{~mm}$ ), wood and Leaf Litter Tissue (LeLT, >1mm), Algae (ALG), Animal Tissue (AT-including whole prey and exoskeleton fragments) and Mineral Material (MM). The proportion occupied by each ingested item was estimated as the area fraction out of the total area covered by the gut contents in each of 15 randomly-selected points on each slide. Photographs of the 15 points were taken and 
the relative areas of the items were estimated using the Micro-Manager 1.3 software.

Predatory taxa, scrapers, collector-filterers and shredders were identified, but we only included the latter for quantitative analyses. To classify the shredder taxa, the relative area covered by each food item in the dissecting glass was used to assign each taxon to one of the two following Functional Shredder Guilds (FSGs): (1) Collector and Shredder (C,Sh), or (2) Shredder sensu stricto (Sh). This classification was tested by a cluster analysis based on Bray-Curtis Distance (based on the average proportion occupied by each food item into the guts of all individuals of each taxon) using BioDiversity Pro (McAleece, Lambshead \& Paterson, 1997). Collector and Shredders (C,Sh) are those individuals consuming CPOM and LeLT in similar proportions, as well as FPOM. Shedders (Sh) are those individuals with $>40 \%$ of their gut contents composed of LeLT or wood fragments (adapted from Cheshire et al., 2005), in this group, specialist-shredders can be identified when $>70 \%$ of their gut contents is LeLT and/or wood; and generalist-shredders when the gut content of LeLT is $<70 \%$.

Data processing. Environmental data and insect abundance from the two sampling months were averaged by reach for the analysis.

1. Dietary overlap. Dietary overlap was quantified using the method of Petraitis (1979). The general overlap (GO) was calculated to account for the niche breadth of each taxon. GO values range between 0 and 1 (from none to complete overlap of the species). The likelihood of this overlap (probability that each species' niche was drawn from a combined niche) was tested using a $\chi^{2}$ distribution, and pairedtaxa comparisons was made. These comparisons were reported as a dendrogram based on Bray-Curtis Distance's Group-Average clustering method using BioDiversity Pro (McAleece et al., 1997).

2. Importance Value Index (IVI) (Lamprecht, 1962) and Importance Percentage (IP) of shredder taxa. These two metrics were useful to assess the overall significance of a species as part of the shredder guild. IVI was calculated by adding three community-based estimates: relative biomass (RB), relative frequency (RF) and relative content of leaf litter tissue in the gut (RLeLT), this is IVI=RB+RF+RLeLT. RB was calculated dividing the total biomass of all individuals of a species by the total biomass of all individuals of all the shredder species (i.e. biomass $\mathrm{sp} 1 / \Sigma$ biomass all species). It was calculated once for all of the taxa in the whole collection. RF and RLeLT were similarly computed. IP was calculated dividing IVI of each species $\left(\mathrm{IVI}_{\mathrm{i}}\right)$ by the total IVI, so: $\mathrm{IP}=\mathrm{IVI}_{\mathrm{i}} /$ Total IVI*100.

3. Shredder-taxa spatial arrangement. The spatial arrangement of shedders was analyzed in four ways: The Index of Dispersion (ID=variance/mean) (Elliott, 1973) of each taxon was calculated across the six streams; if ID $<1$ the distribution is uniform, if ID $>1$ it is contagious (aggregated), and if $\mathrm{ID}=1$ it is random. $\chi^{2}$ distribution $(\mathrm{p}<0.05)$ was used as a significance test (Ludwing \& Reynolds, 1988). The Morisita index $\left(I_{\delta}\right)$ (Morisita, 1971) was computed to analyze the spatial pattern of each taxon; this is unaffected by changes in density caused by random thinning (Myers, 1978). This index was computed as follows:

$$
I_{\delta}=Q \sum_{i=1}^{Q} X_{i}\left(X_{i}-1\right) / \mathrm{N}(\mathrm{N}-1)
$$

where $X_{i}$ is the abundance of a species in the $i$ th stream, Q is the number of streams (6 in this case) and $\mathrm{N}=\Sigma X_{i}$. When $I_{\delta}<1$ the distribution is uniform, $I_{\delta}>1$ contagious and $I_{\delta}=1$ random. $\chi^{2}$ distribution $(\mathrm{p}<0.05)$ was used as a significance test (Rabinovich, 1982). ID and $I_{\delta}$ were also used to determine the spatial arrangement of the leaf morphotypes on the standing stock (quantitative samples), for thus computing patterns of arrangement of food resource used by shredders among streams. Generally, several indices of pattern detection are required as they measure slightly a different aspect of the spatial pattern (Greig-Smith, 1983; Shaukat \& Siddiqui, 2004). 
With ID index and $I_{\delta}$ we determined the spatial arrangement for each taxon, and Iwao's regression model (Iwao, 1979) was used to analyze the spatial arrangement of the guild (31 taxa) among the streams. It relates for each taxon the Lloyd's (1967) mean crowding index $\left(m^{*}\right)$ and the arithmetic mean of abundance of a taxon across the total number of streams $(m)$, as: $m^{*}=\alpha+\beta m$, where $m^{*}$ was determined as: $m^{*}=m+(I D-1)$. The intercept $(\alpha)$ is the index of basic contagion, which indicates whether the basic component of the distribution is a single individual or a group. It also indicates repulsion, isolation or aggregation among individuals when $\alpha<0, \alpha=0, \alpha>0$, respectively. Slope $(\beta)$ is the density contagiousness coefficient, denotes how the basic components are distributed over the space, indicating uniform, random and contagious dispersion when $\beta<1$, $\beta=1, \beta>1$, respectively.

4. Environmental variables and shredders. Linear regression was performed for exploring the relationship among environmental (independent) variables (Table 3) and macroinvertebrate guild metrics (i.e. abundance, richness and biomass). The statistical program used was Statistica 6.0 (Hill \& Lewicki, 2007).

\section{RESULTS}

Non-shredder taxa. Forty eight (48) genera or morphotypes in 24 families were collected out of 4042 individuals observed, 31 genera were classified as shredders (3 316ind.), and 17 genera as non-shredders (726ind). Out of these 17 genera, 9 taxa were classified as predators (574ind.), 2 taxa as collectorsfilterers (135ind.), 2 taxa as scrapers (11ind.), and 4 taxa were not classified due to their low abundance (6ind. in total).

The predatory taxa were Polycentropus and Polyplectropus (Polycentropodidae: Trichoptera), Anacroneuria (Perlidae: Plecoptera), Corydalus (Corydalidae: Megaloptera), Argia (Coenagrionidae: Odonata), Gomphus (Gomphidae: Odonata), Rhagovelia (Veliidae: Hemiptera), Tanypodinae sp. (Chironomidae) and Hexatoma (Tipulidae: Diptera). The scraper taxa $(100 \%$ de their gut contents with FPOM) were Psephenops and Eubriinae sp. (Psephenidae: Coleoptera) and Neritina latissima Broderip snails (observed, not collected). The filterer-collector taxa were Forcipomyia (Ceratopogonidae: Diptera) and Simulium (Simuliidae: Diptera). Predator, scraper and filterer-collector taxa were not quantitatively analyzed in this study.

Functional shredder guild (FSG). The shredder guild included 27 aquatic insect genera, 1 semiaquatic cockroach, 1 amphibious crab and 2 diadromous shrimps. The proportion occupied by each ingested item in the gut of each taxon can be observed in Fig. 2. Amphipods (common shredders in temperate stream) were observed in the field but not found in the samples. The most abundant taxa were Stenochironomus (Chironomidae) (31.3\%), other Chironomidae (except Tanypodinae) (23.6\%), Potimirin c.f. glabra (Atyidae) (11.6\%) and Phanocerus larvae and adults (Elmidae) (5.8 and $5.6 \%$, respectively), while Tricorythodes (Leptohyphidae) $(0.1 \%)$, Hydrophiloidea larvae $(0.1 \%)$, Tipula (Tipulidae) $(0.03 \%)$ and Macrobrachium (Palaemonidae) (0.12\%) were the least abundant organisms within the samples (Table 3). In contrast, the Epilampra (Blaberidae) cockroaches were the most important shredders in terms of biomass, even outnumbering shrimps and crabs (Table 2).

In the FSG, shredders (Sh) sensu stricto accounted for $84 \%$ (26 taxa) of the total number of taxa of guild (31 taxa). Shredders were subdivided into specialists and generalists. Among shredders, the cockroaches, ptilodactylid beetles, crabs and shrimps stood out because they exhibited the largest body size and the higher individual biomass. A few small-body insects were shredders too, such as some ephemeropterans, trichopterans, coleopterans and dipterans. Collector-Shredders (C,Sh) were $16 \%$ (5 taxa) of the total richness of the guild. The collector-shredders were some ephemeropterans, a few of them were predominantly collectors while others were predominantly shredders (Table 2 ). 
TABLE 2

Importance Value Index (IVI) and Importance Percentage (IP) and Functional Feeding Group classification (FFGs) of each shredder taxon at Gorgona Island

\begin{tabular}{|c|c|c|c|c|c|c|c|}
\hline Таха & $\begin{array}{l}\text { Mean biomass } \\
\text { (mg of Ind/sp) }\end{array}$ & Biomass & Frequency & $\begin{array}{l}\text { Leaf litter } \\
\text { tissue }\end{array}$ & $\begin{array}{l}\text { Importance Value } \\
\text { Index (IVI) }\end{array}$ & $\begin{array}{c}\text { Importance } \\
\text { Percentage (IP) }\end{array}$ & FFG \\
\hline Thraulodes & 0.0001 & 0.000176 & 0.03 & 0.009 & 0.04 & 1.27 & C-Sh* \\
\hline Hagenulopsis & 0.0002 & 0.000918 & 0.04 & 0.025 & 0.07 & 2.29 & G-Sh \\
\hline Farrodes & 0.00004 & 0.000114 & 0.04 & 0.005 & 0.04 & 1.35 & C-Sh* \\
\hline Tricorythodes & 0.0003 & 0.000090 & 0.01 & 0.001 & 0.02 & 0.53 & $\mathrm{C}^{*}$-Sh \\
\hline Leptohyphes & 0.0001 & 0.000570 & 0.04 & 0.077 & 0.12 & 4.00 & S-Sh \\
\hline Baetodes & 0.0001 & 0.000051 & 0.03 & 0.001 & 0.03 & 1.00 & C-Sh* \\
\hline Cloeodes & 0.0001 & 0.000115 & 0.04 & 0.008 & 0.04 & 1.47 & C-Sh* \\
\hline Smicridea & 0.0004 & 0.000267 & 0.03 & 0.016 & 0.05 & 1.51 & S-Sh \\
\hline Leptonema & 0.0011 & 0.001359 & 0.03 & 0.009 & 0.04 & 1.30 & G-Sh \\
\hline Phylloicus & 0.0018 & 0.002185 & 0.04 & 0.044 & 0.08 & 2.72 & S-Sh \\
\hline Nectopsyche & 0.0009 & 0.004668 & 0.04 & 0.027 & 0.07 & 2.48 & G-Sh \\
\hline Anchytarsus & 0.0007 & 0.002614 & 0.04 & 0.051 & 0.10 & $\underline{3.20}$ & S-Sh \\
\hline Tetraglosa & 0.0007 & 0.000568 & 0.01 & 0.096 & 0.11 & $\underline{3.69}$ & S-Sh \\
\hline Heterelmis & 0.0001 & 0.000051 & 0.02 & 0.001 & 0.02 & 0.74 & G-Sh \\
\hline Disersus & 0.0017 & 0.006001 & 0.03 & 0.052 & 0.09 & 2.88 & S-Sh \\
\hline Phanocerus L & 0.0001 & 0.002171 & 0.04 & 0.031 & 0.08 & 2.54 & G-Sh \\
\hline Phanocerus A & 0.0002 & 0.003661 & 0.04 & 0.041 & 0.09 & 2.89 & S-Sh \\
\hline Neoelmis & 0.0001 & 0.000204 & 0.04 & 0.029 & 0.07 & 2.16 & G-Sh \\
\hline Macrelmis & 0.0003 & 0.000601 & 0.04 & 0.060 & 0.10 & $\underline{3.21}$ & S-Sh \\
\hline Elodes sp. 1 & 0.0002 & 0.002103 & 0.04 & 0.019 & 0.06 & 2.13 & S-Sh \\
\hline Elodes sp. 2 & 0.0002 & 0.001255 & 0.03 & 0.017 & 0.05 & 1.57 & G-Sh \\
\hline Hydrophiloidea A & 0.0004 & 0.000441 & 0.04 & 0.010 & 0.05 & 1.53 & G-Sh \\
\hline Hydrophiloidea L & 0.0002 & 0.000068 & 0.03 & 0.010 & 0.04 & 1.28 & S-Sh \\
\hline Tipula & 0.00003 & 0.000002 & 0.01 & 0.036 & 0.04 & 1.44 & S-Sh \\
\hline Chironomidae (except Tanypodiinae) & 0.00003 & 0.002327 & 0.04 & 0.012 & 0.06 & 1.89 & G-Sh \\
\hline Stenochironomus & 0.0001 & 0.006168 & 0.04 & 0.096 & 0.15 & 4.83 & S-Sh \\
\hline Maruina & 0.0006 & 0.000376 & 0.02 & 0.017 & 0.04 & 1.29 & G-Sh \\
\hline Epilampra & 0.1563 & 0.703893 & 0.04 & 0.096 & 0.84 & 27.93 & S-Sh \\
\hline Potimirim & 0.0073 & 0.239346 & 0.04 & 0.038 & 0.32 & 10.62 & G-Sh \\
\hline Macrobrachium & 0.0070 & 0.002374 & 0.01 & 0.023 & 0.04 & 1.31 & G-Sh \\
\hline H. gorgonensis & 0.09 & 0.015264 & 0.01 & 0.059 & 0.09 & 2.95 & S-Sh \\
\hline TOTAL & & & & & 3.02 & 100.00 & \\
\hline
\end{tabular}

(C-Sh: Collector-Shedder, G-Sh: Generalist-Shredder, S-Sh: Specialist-Shredders. *Indicates dominant function).

CPOM, FPOM and LeLT were common food items in the gut contents of macroinvertebrates dwelling in leaf litter packs in Gorgona Island, but despite the general niche overlap, preferences differed among taxa. Regarding the four groups observed in Fig. 2, they can be pooled into the following categories: (1) Shredder s.s. (groups I, II, III), and (2) Collector- Shredder (group IV). Shredders were subdivided into: (a) specialist-shredders (groups I and II); and (b) generalist-shredders (group III). Both subgroups were consumers of LeLT, with a relatively high diet overlap. Specialist-shredders such as Tipula, Elodes, Phanocerus, Disersus, Macrelmis and Smicridea supplemented their diet of LeLT with a small fraction of FPOM and CPOM. In contrast, generalist-shredders fed upon equal 


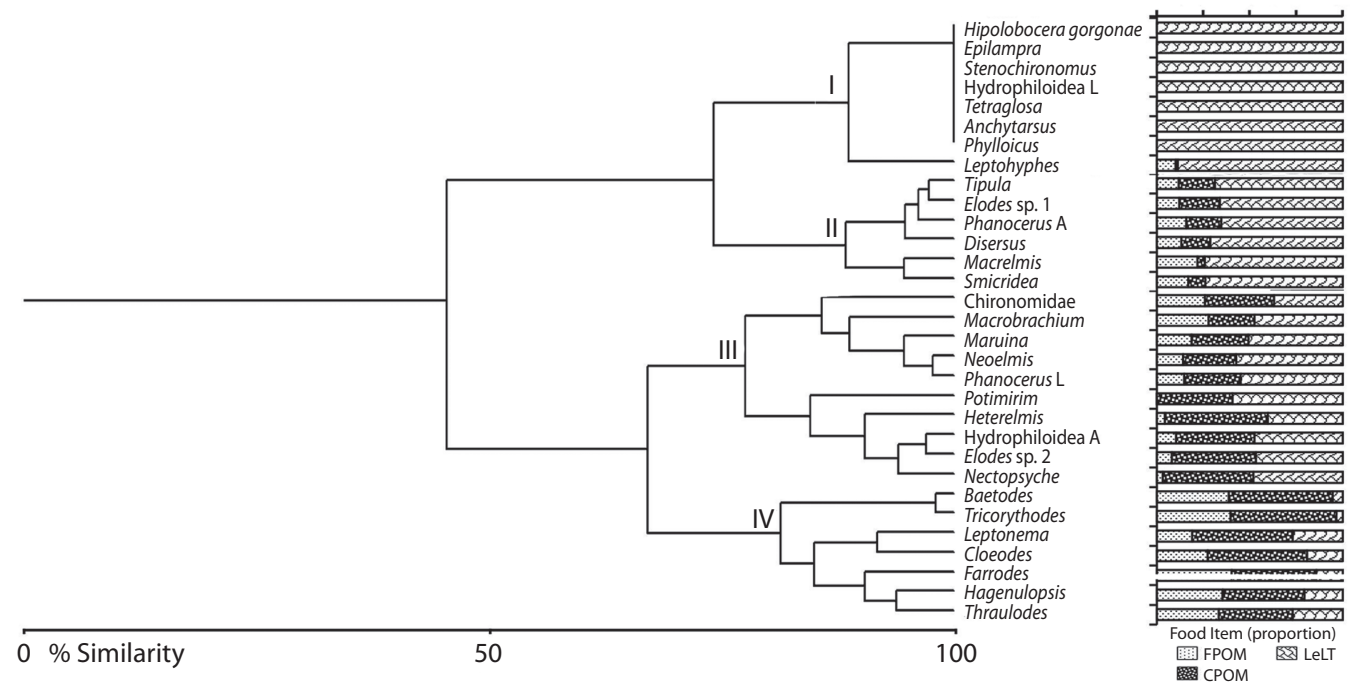

Fig. 2. Cluster analysis of trophic spectrum of 31 macroinvertebrate genera showing overlap of trophic niche. Bray-Curtis Distance Group-Average was used as the clustering method. The horizontal bars show the percent of items in guts. The dependence of Leaf Litter Tissue (LeLT) as important food source of the guild is remarkable.

proportions of CPOM and LeLT (group III: several orders of macroinvertebrates). The collector-shredders mainly consumed CPOM and FPOM (group IV: exclusively represented by mayflies). Although, Hagenulopsis and Leptonema were classified into the group IV, these taxa were considered as generalist-shredders finally, due the high proportion of CPOM and LeLT in their gut contents.

Dietary overlap. There was a complete dietary niche overlap $(G O=0.75, \mathrm{p}<0.001)$ for the shredder guild. Complete overlap was also observed among species within the specialist-shredder group (group II in Fig. 2) (Hipolobocera gorgonensis, Epilampra, Stenochironomus, Hydrophiloidea (L), Tetraglosa, Anchytarsus and Phylloicus). In group I, also specialist-shredders, a high dietary overlap (95\%) was also detected among Tipula, Elodes sp. 1, Phanocerus (A) and Disersus as well as between Macrelmis and Smicridea. In group III, the similarity was due to the amount of FPOM, CPOM and LeLT, but two subgroups were observed ( 86 and $84 \%$ ). In group IV, all Ephemeroptera were grouped together in terms of dietary overlap (81\%). These results were consistent with specific (pairwise) niche overlap (not shown).

Importance of each taxon for the FSG. Cockroaches were the taxon with the highest IP due to their high relative biomass and LeLT content in their guts (Table 2). These organisms were more important than shrimps and crabs in terms of both abundance and biomass. P. glabra ranked second and Stenochironomus ranked third place. Among aquatic insects, other secondarily important species were Leptohyphes, Tetraglosa, Macrelmis and Anchytarsus (Table 2).

Shredder taxa spatial arrangement. Ten species out of 31, yielded variance/mean ratios significantly greater than 1 , the expected ratio for random distribution, thus exhibiting a contagious spatial pattern (Table 2); this was corroborated with Morisita's index. The remaining twenty one species exhibited a random (Poisson) distribution. Similarly, 185 (84.1\%) out of the 220 leaf morphotypes identified from the leaf litter standing stock, exhibited a random 
distribution, $18(8.2 \%)$ a contagious pattern, and $17(7.7 \%)$ a uniform distribution (data not shown). Therefore, the overall resource distribution among streams was random.

In Iwao's regression model (Fig. 3), the slope $(\beta=1.95)$ was significantly different from the unity ( $\mathrm{t}=29.09 ; \mathrm{p}<0.001)$, and the intercept (a) was non-significantly different from zero $(\alpha=-2.35 ; \mathrm{t}=-1.69 ; \mathrm{p}>0.05)$. $\beta$-value can be regarded as a mean contagion index of the guild at the scale at which the sampling was performed, but according with the observed on Fig. 3, the slope was highly influenced by the few taxa with contagious distribution [i.e. 10 taxa (Table 3), 7 of them are named in the Fig. 3]. A negative $\alpha$ indicated that individuals tend to repulsion, and these results were highly influenced by the taxa located close to the origin, exhibiting a random arrangement. Therefore, although $\alpha$ was not significantly different from zero, it was consistent with the random distribution of most taxa at individual level (Table 3), and hence, the repulsive tendency of individuals tested in the Iwao's model.

\section{Environmental variables and shredders.}

Mean abundance, richness and mean biomass of FSG were not significantly correlated with any environmental variable (Table 1$)\left(\mathrm{r}^{2}\right.$ values range: 0.001-0.216; all p-values were $>0.05$, not shown).

\section{DISCUSSION}

Shredder guild composition, structure and importance. Shredder richness (including specialist-shredders, generalist and collectorshredders) was relatively higher (31 taxa) in Gorgona Island compared to many other insular and continental tropical locations. This figure even exceeded reports from tropical sites where shredders are seemly abundant and rich such as Malaysia (22 species; Yule et al., 2009), and northern Australia, Panama, Bolivia and Ecuador (all with $<16$ taxa; Cheshire et al., 2005; Camacho et al., 2009; Tomanova et al., 2006; Ríos, Encalada \& Prat, 2009; Boyero et al., 2011a; b). Our results provide further evidence against the hypothesis of a generalized poverty and scarcity of shredder macroinvertebrates in the tropics, supporting recent arguments by Cheshire et al. (2005), Camacho et al. (2009) and Ríos et al. (2009).

Furthermore, our results suggest that shredders in tropical streams do not necessarily consist of Plecoptera and Trichoptera as in temperate streams, because in the tropics, some taxa of Ephemeroptera, Coleoptera and Blattodea also are relevant shredders in relation to the abundance and biomass of this guild. While it is widely documented that shrimps and crabs are dominant shredders in lowland tropical coastal and island streams (March, Benstead, Pringle \& Ruebel, 2001; Dobson, Magana, Mathooko

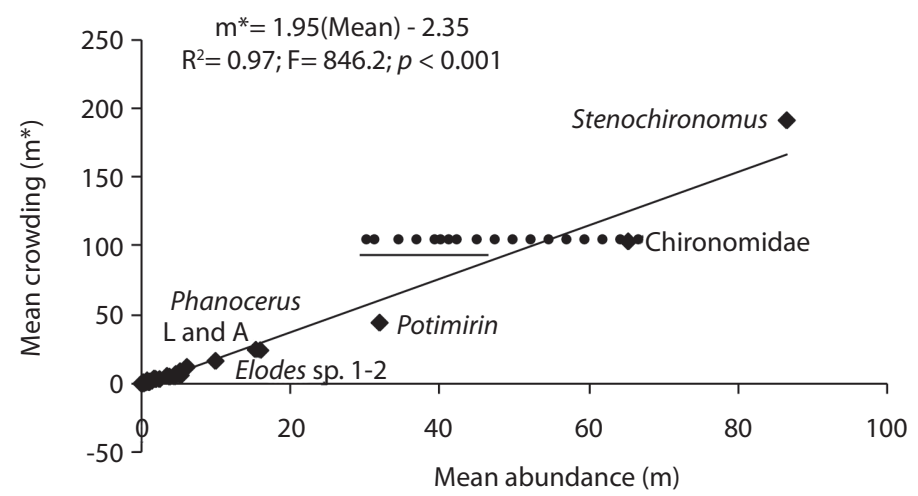

Fig. 3. Iwao's regression model with mean crowding $\left(\mathrm{m}^{*}\right)$ plotted against mean abundance $(\mathrm{m})$ for the shredder guild. The labeled taxa showed a contagious spatial arrangement (Hagenulopsis, Leptohyphes and Disersus are not clearly distinguished). The rest of taxa (unlabeled points) exhibited a random arrangement. (L: Larvae, A: Adult). 
TABLE 3

Total density, Variance-Mean ratio (V/M) and Morisita's index with its significance levels

\begin{tabular}{|c|c|c|c|c|c|}
\hline Order & Taxa & $\begin{array}{l}\text { Total abundance } \\
\text { (ind./sample) }\end{array}$ & $V / M$ ratio & $\begin{array}{l}\text { Morisita's } \\
\text { index }\end{array}$ & Distribution \\
\hline \multirow[t]{7}{*}{ Ephemeroptera } & Thraulodes & 11.5 & 2.1 & 1.5 & Random \\
\hline & Hagenulopsis & 28.0 & $2.8^{*}$ & 1.3 & Contagious \\
\hline & Farrodes & 15.0 & 1.3 & 1.1 & Random \\
\hline & Tricorythodes & 2.0 & 1.1 & 1.5 & Random \\
\hline & Leptohyphes & 31.5 & $4.2 * * *$ & $1.5^{* *}$ & Contagious \\
\hline & Baetodes & 6.0 & 0.7 & 0.7 & Random \\
\hline & Cloeodes & 8.5 & 1.0 & 1.0 & Random \\
\hline \multirow[t]{4}{*}{ Trichoptera } & Smicridea & 3.5 & 0.6 & 0.2 & Random \\
\hline & Leptonema & 7.0 & 0.8 & 0.9 & Random \\
\hline & Phylloicus & 7.0 & 0.7 & 0.7 & Random \\
\hline & Nectopsyche & 32.0 & 1.2 & 1.0 & Random \\
\hline \multirow[t]{12}{*}{ Coleoptera } & Anchytarsus & 23.0 & 1.7 & 1.2 & Random \\
\hline & Tetraglosa & 5.0 & 2.0 & 2.3 & Random \\
\hline & Heterelmis & 3.0 & 0.8 & 0.5 & Random \\
\hline & Disersus & 21.0 & $2.6^{*}$ & 1.4 & Contagious \\
\hline & Phanocerus L & 96.0 & $8.7 * * *$ & $1.4^{* * *}$ & Contagious \\
\hline & Phanocerus A & 92.5 & $9.7 * * *$ & $1.5^{* * *}$ & Contagious \\
\hline & Neoelmis & 12.0 & 1.7 & 1.3 & Random \\
\hline & Macrelmis & 10.5 & 2.3 & 1.7 & Random \\
\hline & Elodes sp. 1 & 60.0 & $7.0 * * *$ & $1.5^{* * *}$ & Contagious \\
\hline & Elodes sp. 2 & 37.0 & $6.5 * * *$ & $1.8^{* * *}$ & Contagious \\
\hline & Hidrophiloidae A & 6.5 & 0.4 & 0.5 & Random \\
\hline & Hidrophiloidae L & 2.0 & 0.2 & 0.0 & Random \\
\hline \multirow[t]{4}{*}{ Diptera } & Tipula & 0.5 & 0.5 & 6.0 & Random \\
\hline & Chironomidae (except Tanypodiinae) & 392.0 & $38.8 * * *$ & $1.5^{* * *}$ & Contagious \\
\hline & Stenochironomus & 519.5 & $105.6^{* * *}$ & $2.0^{* * *}$ & Contagious \\
\hline & Maruina & 3.5 & 0.8 & 0.5 & Random \\
\hline Dictyoptera & Epilampra & 27.0 & 1.2 & 1.0 & Random \\
\hline \multirow[t]{3}{*}{ Decapoda } & Potimirim & 192 & $12.9 * * *$ & $1.3 * * *$ & Contagious \\
\hline & Macrobrachium & 2.0 & 1.1 & 1.5 & Random \\
\hline & H. gorgonensis & 1.0 & 0.4 & 0.0 & Random \\
\hline
\end{tabular}

$\left({ }^{*} \mathrm{p}<0.05 ; * * \mathrm{p}<0.01 ; * * * \mathrm{p}<0.001\right)(\mathrm{L}:$ Larvae, A: Adult).

\& Ndegwa, 2002; Crowl et al., 2006), semiaquatic cockroaches were recently reported as important shredders by their biomass (Yule et al., 2009), along with coleopterans (larvae and adult) and mayflies that have an important role too (Ríos et al., 2009; Bello \& Cabrera 2001; Wantzen \& Wagner, 2006; Chará-Serna et al., 2010). Mayflies, traditionally considered as collectors in temperate regions, have been identified as shredders or collector-shredders in some tropical regions (based on gut content); examples include Baetodes in Ecuador (Ríos et al., 2009), Farrodes sp. 2 and Terpides in Venezuela (Bello \& Cabrera, 2001), Farrodes and Tricorythodes in Brazil (Wantzen \& Wagner, 2006) and Tricorythodes in Colombia (Chará-Serna et al., 2010). Similarly, within the Coleoptera, several taxa (or morphotypes) of Elmidae have been considered as collectorshredders in the Tropics (Cheshire et al., 2005; 
Wantzen \& Wagner, 2006). However, in Brazil, Baptista et al. (2006) classified Farrodes carioca Dominguez, Hagenulopsis spp., and Thraulodes sp., as brushers; while Leptohyphes sp., and Tricorythodes sp., were considered as scrapers; and Baetodes sp., and Cloeodes spp., as grazers. In Brazil, Cloeodes sp. was found to assimilate predominantly microalgae (Brito, Moulton, Souza, \& Bunn, 2006) and to be an important grazer of periphyton (Moulton, Silveira \& Krsulovic, 2004), among others. In this study, we additionally reported the following taxa as shredders: Thraulodes, Hagenulopsis, Leptohyphes and Cloeodes (ephemeropterans), and Heterelmis, Disersus, Phanocerus, Neoelmis, Macrelmis and one taxon of Hydrophiloidea (coleopterans) (Table 4).

In the present study, we found that semiaquatic cockroaches are the main shredders, although shrimps and crabs are as common as in insular streams elsewhere. Cockroaches do not only specialize on feeding upon leaf litter tissues but also they exceeded the coexisting decapods and a rich aquatic-insect assemblage in terms of individual biomass. Hipolobocera gorgonensis crabs and Macrobrachium spp. shrimps were found within the leaf litter only as juveniles. In addition, Potimirin c.f. glabra shrimps reached a small body size as adults. Out of the shredder guild total biomass (20.3mgAFDM/sample), $91.4 \%$ (18.5mg) corresponded to cockroaches, $7.5 \%(1.52 \mathrm{mg})$ to decapods and $1.1 \%(0.23 \mathrm{mg})$ to aquatic insects.

Biomass is one of the main indicators of community structure from a functional standpoint, because it is a reflection of the energy flow and resource use relative to metabolic and environmental factors (Huryn \& Benke, 2007; Townsend \& Thompson, 2007; Poff et al., 1993). Accordingly, taxa with the greatest per capita or population biomass would be functionally more important than taxa of comparable or greater abundance but less individual or population biomass. Therefore, due to their high individual biomass and abundance, cockroaches seem to be the most important processors of the leaf litter input from rainforests in Gorgona Island, and probably in other continental islands in the Tropical Eastern Pacific (e.g. Coiba).

The second most important taxon was the atyid Potimirin c.f. glabra, which surpassed the palaemonid Macrobrachium spp. in terms of abundance. These differences in abundance are in agreement with those reported by Souza \& Moulton (2005) for an island in Brazil, but differ from results in the Caribbean, where the atyids Atya spp. and Macrobrachium spp. and the xiphocariid Xiphocaris elongata are the most abundant taxa (Benstead, March \& Pringle, 2000). However, the consensus is that the feeding strategy (i.e. scrapers, filterers or shredders) in stream decapods depends on the flow and the food resources (Covich, 1988), and on the developmental stage, because some species are partial shredders as juveniles, but they are mostly omnivores and predators as adults (Covich, 2006b).

Dietary overlap. Although the trophic overlap of taxa was high, different pathways were identified for the leaf litter during the shredding process according to ingested-particle size and proportion. Understanding organic detritus pathways is important in decomposition studies (Covich, 2006b). In Gorgona streams, semi-aquatic and aquatic insect species and some decapods shred the leaf litter, created CPOM and FPOM in suspension as part of the shredding process. These suspended particles become available to be consumed by other small-bodied shredders that are not able to consume coarse tissues.

\section{Shredder guild spatial arrangement} island-wide. In general, shredder taxa were broadly distributed across the island and no significant relationship was observed between abundance of any taxa and any of the sampled environmental variables including type of geology, conservation status of the riparian forests and detritus diversity and biomass. This suggests that the habitat template is not variable enough to exert a limitation for the guild. For instance, leaf litter inputs may be high enough to provide basal resources for shredders (see 


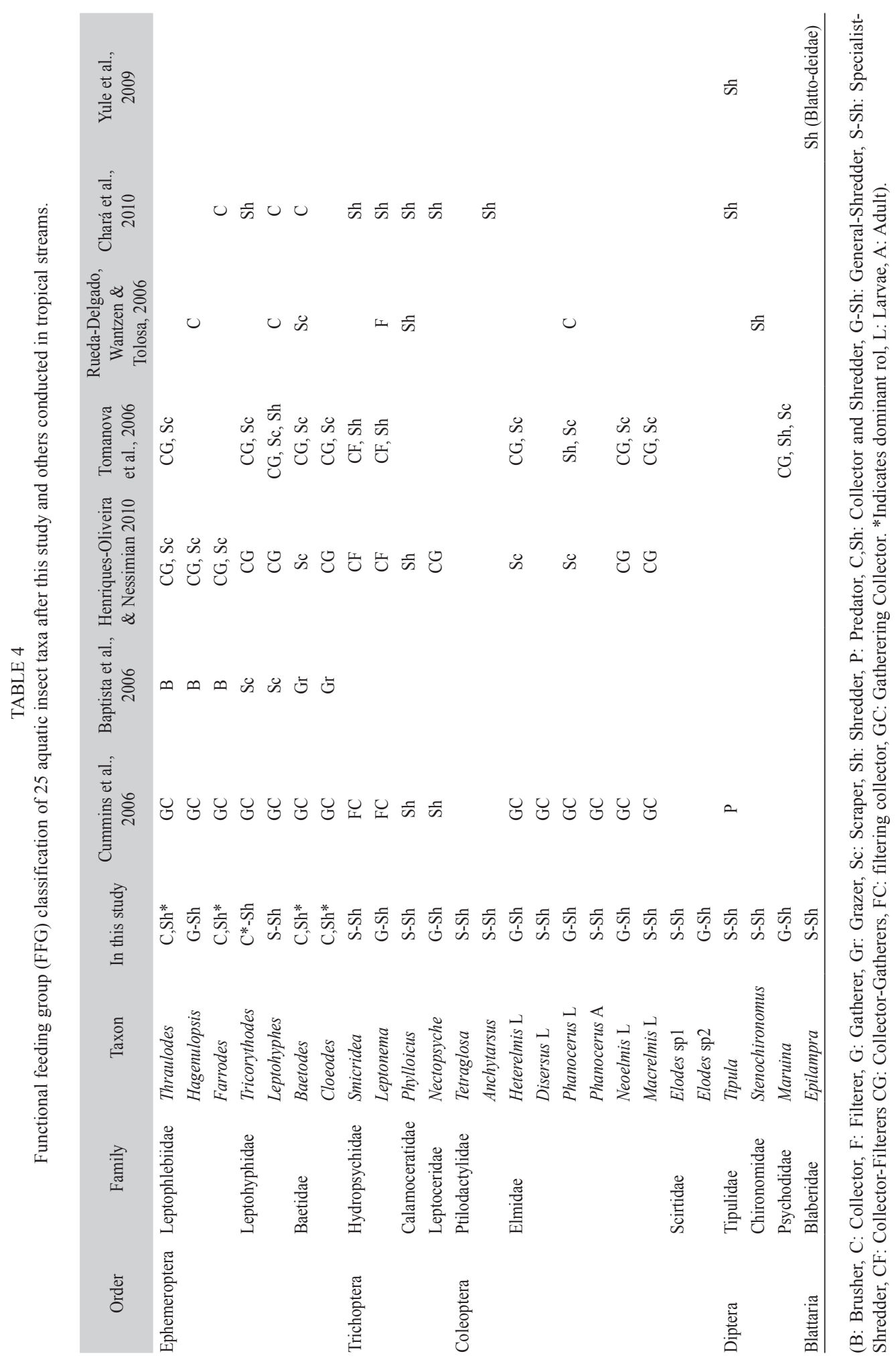


below). In addition, despite the great richness of leaf morphotypes, either differences among streams are not functionally significant or leaf quality is not different. Regarding the composition of riparian forests, Graça et al., (2001) in an experiment with various types of leaves found that shredders did not discriminate between indigenous or exotic leaf species in feeding trials. Besides, Yule et al., (2009) did not find, as we did, a significant correlation between biomass and richness of leaf litter with the structure of the shredder guild (i.e. abundance, biomass and richness).

According to our observations and those by Valencia et al. (2009), approximately 290 species or morphotypes of leaf litter have been identified from Gorgona Island streams, and mean richness by stream-reach $(10 \mathrm{~m})$ was 56 species. The number of leaves per reach ranged between 65 and 395 (randomly collected). Actual richness and abundance of leaf litter in streams may be higher, because our study was limited to two sampling periods, and we are aware that leaves can be easily flushed by flash-floods and many small leaves are not entrained in the patchily-distributed standing leaf packs and debris dams. In our study, leaf litter standing stock range was 3.7-60.6gAFD$\mathrm{Mm}^{-2}$, similar to that found by Colón-Gaud et al. (2008) in forested streams in Panama and by Li \& Dudgeon (2008) in Hong Kong, but different from those reported by Yule (1996a) in New Guinea $\left(40-230 \mathrm{gDW} \cdot \mathrm{m}^{-2}\right)$, by Brito et al. (2006) in Brazil (45.9-146gDW.m ${ }^{-2}$ ) and by Cummins et al. (1989) for northern temperate streams (200-900gDW.m $\left.{ }^{-2}\right)$, thus suggesting that Gorgona Island streams probably receive relatively high amounts of allochthonous litter inputs but have low in-stream storage. Such a high richness and abundance of allochthonous organic matter constitutes the basis of the food supply for macroinvertebrates, as generally accepted for closed-canopy, low-order streams in temperate zones (Vannote, Minshall, Cummins, Sedell \& Cushing, 1980). Shredder richness is higher than that of scrapers in such streams, and this pattern has been reported for some Australian tropical streams (Cheshire et al., 2005). Scrapers and grazers in Gorgona Island are scarce, only Psephenops and Eubriinae sp., as insects, and $N$. latissima as snails were found, this latter restricted to a few tens of meters from the confluence to the ocean (this study, Gómez-Aguirre et al., 2009). This pattern can be due to the low epilithic algal growth due to low light transmission through the canopy (personal observation) and the low dissolved nutrient concentration. Besides, microalgae were not observed in any gut content regardless of the feeding group analyzed (shredders, scrapers and predators).

Spatial arrangement. The fact that most shredder taxa showed a random and not contagious distribution among streams may explain the lack of relationship between environmental variables and the guild. The low population density has been pointed as a main cause of randomness (Taylor, 1984). The random distribution of some insects can be considered a strategy of survival in environments with constant disturbances upon substrates or other physical habitat. In Gorgona Island streams, frequent flash flooding is an important aseasonal disturbance; hence, the colonization rate of these resources should be rapid and should exist high dispersal ability in most taxa. It has further been found that with randomness, the terrestrial insects prevent cannibalism, disease, predator attraction, and, perhaps most important, resource depletion (Dethier, 1959; Petitt \& Wietlisbach, 1992; Dhandapani, Jayaraj \& Rabindra, 1993; Schlegel \& Bauer, 1994).

However, the most abundant taxa (1/3 of the total) exhibited a high mean crowding index, and therefore as a whole, the shredder guild can be considered as contagiously distributed (Fig. 2, Table 2). The most salient example of contagious distribution was observed in Chironomidae and Stenochironomus. Dipterans are generally the dominant taxa in most islands, including remote oceanic islands (Bass, 2003; Craig, 2003). A likely explanation is that preferred leaves within the streams were in excess (as observed by Peckarsky, 1980, elsewhere), and then leaf litter standing stock could act 
as a determinant of the distribution of these shredders among streams. These taxa were associated with leaves of specific families such as Sapotaceae (3 species), Lauraceae (2 species), Euphorbiaceae (2) unidentified species, Hieronyma sp.1 and sp.2, Pera, Mabea, and Alchornea, Combretaceae (1 species), Caesalpiniaceae (Bauhinia), Rubiaceae (1 species), Bombacaceae (Ochroma pyramidale), Clusiaceae (1 unidentified sp and Clusia), Mimosacea (3 species of Inga) and Moraceae (1 species). This information can be relevant for future decomposition studies. P. glaba shrimps were also patchily distributed. However, we do not rule out that the results on contagious and random distributions of taxa in Gorgona Island are an artifact of sampling method and of the low number of campaigns, so, we recommend further research.

Although we did not observe that shredder richness changes with increasing riparian leaf species richness in streams, according to Swan \& Palmer (2004) certain leaf litter combinations may lead to strong non-additive effects on ecosystem-level processes (e.g. breakdown, respiration, nutrient availability) and community-level properties [e.g. invertebrate species composition (Hansen, 2000); inter-specific relationships between macro- and microorganisms (Lavelle, Lattaud, Trigo \& Barois, 1994)]. In this sense, to better understand the relationship between shredders and leaf litter richness, it is necessary to identify the "key leaf species" from the pool and what are their effects (positive or negative) on the composition and role of shredders (Wardle, Bonner \& Nicholson, 1997).

Finally, three factors seemingly explain the high richness and abundance of shredders in Gorgonal Island, as a model continental island: (1) its continental origin, (2) its current proximity to the continent $(35 \mathrm{~km})$, and (3) the high diversity and availability of leaf litter and woody debris inputs to the streams. We agree with Cheshire et al. (2005) who propose that the scarcity of shredders in tropical zones may be more a biogeographical than a simple latitudinal/climatic issue. We recommend conducting more research in other continental islands to validate our findings. For instance, the low abundance and biomass of insect shredders along 4 coastal streams in Trinidad (Turner, Williams \& Alkins-Koo, 2008 ) is in contrast to our results. Besides, we found that although crabs, shrimps, aquatic insects and semiaquatic-cockroaches coexisted in Gorgona Island streams, cockroaches may be more important for the ecosystem function due to their contribution in biomass to the shredder guild and due to the high amount of leaf litter found in their guts. We suggest testing the generality of this pattern in other continental islands and coastal streams.

\section{ACKNOWLEDGMENTS}

This research was funded by the GIS-BIO Project (code 551) "Gorgona Island Stream Bioassessment", supported by the Comite para el Desarrollo de la Investigación (CODI) of Universidad de Antioquia to Juan F. Blanco, and a doctoral fellowship to Magnolia Longo from the same University. We thank to Unidad Administrativa Especial del Sistema de Parques Nacionales Naturales de Colombia (UAESPNN-Gorgona) for issuing the research permit DTSO-G-03/08. We thank to A. Gómez, E. Parra, H. Montaño, J. Bonilla, Teo, and Alonso for assistance in the field. Thanks are also due to Armando, Goyo, Colacho, and Guasa for logistical support and sharing their knowledge about the island. Laboratory space and equipment at Universidad de Antioquia was provided by the Limnology Group (LimnoBasE-Biotamar). The following people provided taxonomic assistance: E. Domínguez, C. Molineri, C. Nieto (Ephemeroptera), V. Manzo (Elmidae), F. Romero (Lepidoptera), S. Mazzuconi (Hemiptera) P. Torres, M. Michat, A. Bachmman (Coleoptera), E. Tejerina, A. Paggi (Chironomidae). Special thanks to L. Forero, S. Cadavid, L. Gómez, P. Lizarazo and S. Valencia. J.J. Ramírez for contributed with statistical analysis and commentaries, and thanks to L. Ortíz. Special thanks to the reviewers for their contributions. ELICE Publication No. 16. 


\section{RESUMEN}

Existe la posibilidad de que los macroinvertebrados fragmentadores hayan sido subvalorados en las quebradas tropicales debido al sesgo geográfico de los estudios realizados, a limitaciones metódicas y a la influencia de factores de escala local. A pesar de que los fragmentadores son escasos en las quebradas de islas oceánicas, hipotetizamos que son abundantes en Isla Gorgona. Los análisis de contenidos estomacales de estos organismos se usaron para identificar los taxones fragmentadores colectados en quebradas con diferentes tipos de bosque. Se cuantificaron el índice general de sobreposición dietaria ( $G O$ por su siglas en inglés), y el índice de valor de importancia de cada taxón en el gremio (con base en biomasa relativa, frecuencia relativa y proporción de tejido vegetal en los contenidos estomacales). El arreglo espacial de cada taxón y el del gremio entre quebradas (i.e., contagioso o aleatorio) se determinó a partir de varios índices. Se identificaron 31 fragmentadores, los cuales se dividieron en especialistas (14 taxones), generalistas (10) y colectores-fragmentadores (7). Hubo un $G O$ completo del gremio $(0.75, p<0.001)$. Debido a su alta contribución de biomasa y de abundancia al gremio, y a la elevada proporción de tejido vegetal consumido, las cucarachas (Epilampra) fueron los fragmentadores-especialistas más representativos, superiores incluso a camarones y cangrejos. El camarón Potimirin fue el segundo taxón más importante seguido por el díptero Stenochironomus. Entre los insectos acuáticos, otros taxones de importancia secundaria fueron Leptohyphes (Ephemeroptera), Macrelmis, Anchytarsus y Tetraglosa (Coleoptera). Diez taxones mostraron un patrón espacial de contagio, y 21 se organizaron aleatoriamente, al igual que los recursos (i.e., "paquetes" de hojarasca). Aunque el gremio se organizó contagiosamente, estos resultados pudieron estar altamente influenciados por los taxones con distribución del mismo tipo. No se encontraron correlaciones significantes entre la abundancia media, la riqueza y la biomasa media con ninguna de las variables ambientales. Tres factores explicaron la alta riqueza y la abundancia de los fragmentadores en Isla Gorgona: (1) el origen continental, (2) su proximidad al continente $(35 \mathrm{~km})$, y (3) la alta diversidad y disponibilidad de hojarasca y de desechos de madera dentro de las quebradas. Aunque cangrejos, camarones, insectos acuáticos y cucarachas-semiacuáticas coexistieron en la isla, estas últimas fueron, en términos de biomasa, los fragmentadores más importantes.

Palabras clave: trituradoras, hojarasca, la superposición en la dieta, la disposición espacial.

\section{REFERENCES}

Aristizábal-García, H. (2002). Los hemípteros de la película superficial del agua en Colombia. Parte 1: Familia Gerridae. Guadalupe LTDA: Bogotá, Colombia.

Baptista, D. F., Buss, D. F., Dias, L. G. Nessimian, J. L. Silva, E. R. D., Moraes-Neto, A. H. A. D., Carvalho, S. N. D., Oliveira, M. A. D. \& Andrade, L. R. (2006). Functional feeding groups of Brazilian Ephemeroptera nymphs: ultrastructure of mouthparts. Annales de Limnologie-International Journal of Limnology, 42: 87-96.

Bass, D. (2003). A comparison of freshwater macroinvertebrate communities on small caribbean islands. Bioscience, 53: 1094-1100.

Bello, C. L. \& Cabrera, M. I. (2001). Alimentación ninfal de Leptophlebiidae (Insecta: Ephemeroptera) en el Caño Paso del Diablo. Revista de Biología Tropical, 49: 999-1003.

Benbow, M. E., Mcintosh, M. D., Burky, A. J. \& Way, C. M. (2005). The influence of stream flow reduction on the energetic of endemic Hawaiian torrenticolous aquatic insects, Telmatogeton schiner and Procanace hendel. Journal of Insect Conservation, 9: 175-185.

Benstead, J. P., March, J. G. \& Pringle, C. M. (2000). Estuarine larval development and upstream postlarval migration of freshwater shrimps in two tropical rivers of Puerto Rico. Biotropica, 32: 545-548.

Benstead, J. P., March, J. G., Pringle, C. M., Ewel, K. C. \& Short, J. W. (2009). Biodiversity and ecosystem function in species-poor communities: community structure and leaf litter breakdown in a Pacific island stream. Journal of the North American Benthological Society, 28: 454-465.

Blanco, J. F. (2009). The hydroclimatology of Gorgona Island: seasonal and ENSO-related patterns. Actualidades Biológicas, 31: 111-121.

Boyero, L. \& Bailey, R. C. (2001). Organization of macroinvertebrate communities at a hierarchy of spatial scales in a tropical stream. Hydrobiología, 464: 219-225.

Boyero, L., Ramírez, A., Dudgeon, D. \& Pearson, R. G. (2009). Are tropical streams really different? Journal of the North American Benthological Society, 28: 397-403.

Boyero, L., Pearson, R. G., Dudgeon, D., Ferreira, V., Graça, M. A. S., Gessner, M. O., Boulton, E. C., Yule, 
C. M., Albariño, R. J., Ramírez, A., Helson, J. E., Callisto, M., Arunachalam, M., Chará, J., Figueroa, R., Mathooko, J. M., Gonçalves Jr., J. F., Moretti, M. S., Chará-Serna, A. M., Davies, J. N., Encalada, A., Lamothe, S., Buria, L. M., Castela, J., Cornejo, A., Li, A. O. Y., M'Erimba, C., Díaz-Villanueva, V., Zúñiga, M. C., Swan, C. M. \& Barmuta, L. A. (2011a). Global patterns of stream detritivore distribution: implications for biodiversity loss in changing climates. Global Ecology and Biogeography, 21: 134-141.

Boyero, L., Pearson, R. G., Dudgeon, D., Graça, M. A. S., Gessner, M. O., Albariño, R. J., Ferreira, V., Yule, C. M.,Boulton, A. J., Arunachalam, M., Callisto, M., Chauvet, E., Ramírez, A., Chará, J., Moretti, M. S., Gonçalves Jr. J. F., Helson, J. E., Chará-Serna, A. M., Encalada, A. C., Davies, J. N., Lamothe, S., Cornejo, A., Li, A. O., Buria, L. M., Villanueva, V. D., Zúñiga, M. C. \& Pringle, C. M. (2011b). Global distribution of a key trophic guild contrasts with common latitudinal diversity patterns. Ecology, 92: 1839-1848.

Brito, E. F., Moulton, T. P., Souza, M. L. \& Bunn, S. E. (2006). Stable isotope analysis indicates microalgae as the predominant food source of fauna in a coastal forest stream, south-east Brazil. Austral Ecology, 31: 623-633.

Camacho, R., Boyero, L., Cornejo, A., Ibáñez, A. \& Pearson, R. G. (2009). Local variation in shredder numbers can explain their oversight in tropical streams. Biotropica, 41: 625-632.

Chará-Serna, A. M., Chará, J. D., Zúñiga, M. C., Pedraza, G. X. \& Giraldo, L. P. (2010). Clasificación trófica de insectos acuáticos en ocho quebradas protegidas de la ecorregión cafetera colombiana. Universitas Scientiarum, 15: 27-36.

Cheshire, K., Boyero, L. \& Pearson, R. G. (2005). Food webs in tropical Australian streams: shredders are not scarce. Freshwater Biology, 50: 748-769.

Chown, S. L., Lee, J. E. \& Shaw, J. D. (2008). Conservation of Southern Ocean Islands: invertebrates as exemplars. Journal of Insect Conservation, 12: 277-291.

Choy, S. (1991). The atyid shrimps of Fiji with description of a new species. Zoologische Mededelingen, 65: 343-362.

Colón-Gaud, C., Peterson, S., Whiles, M. R., Kilham, S. S., Lips, K. R. \& Pringle, C. M. (2008). Allochthonous litter inputs, organic matter standing stocks, and organic seston dynamics in upland Panamanian streams: potential effects of larval amphibians on organic matter dynamics. Hydrobiología, 603: 301-312.

Covich, A. P. (1988). Atyid shrimp in the headwaters of the Luquillo Mountains, Puerto Rico: filter feeding in natural and artificial streams. Verhandlungen der Internationale Vereinigung für theorestische und angewandte Limnologie, 23: 2108-2113.
Covich, A. P. (2006a). Dispersal-limited biodiversity of tropical insular streams. Polish Journal of Ecology, 54: 523-547.

Covich, A. P. (2006b). Protección de la biodiversidad del bentos para asegurar procesamiento de materia orgánica y servicios del ecosistema: importancia de los invertebrados fragmentadores en redes de drenaje. Ecotropicos, 19: 109-127.

Covich, A. P., Crowl, T .A. \& Heartsill-Scalley, T. (2006). Effects of drought and hurricane disturbances on headwater distributions of palaemonid river shrimp Macrobrachium spp. in the Luquillo Mountains, Puerto Rico. Journal of the North American Benthological Society, 25: 99-107.

Craig, D. A. (2003). Geomorphology, development of running water habitats, and evolution of black flies on Polynesian islands. BioScience, 53: 1079-1093.

Crowl, T.A., McDowell, W. H., Covich, A. P. \& Johnson, S. L. (2001). Species-specific responses in leaf litter processing in a tropical headwater stream (Puerto Rico). Ecology, 82: 775-783.

Crowl, T. A., Welsh, V. \& Heartsill-Scalley, T. (2006). Effects of different types of conditioning on rates of leaf-litter shredding by Xiphocaris elongata, a Neotropical freshwater shrimp. Journal of the North American Benthological Society, 25: 198-208.

Cummins, K. W. (1973). Trophic relations of aquatic insects. Annual Review of Entomology, 18: 183-206.

Cummins, K. W., Wilzbach, M. A., Gates, D. M., Perry, J. B. \& Taliaferro, W. B. (1989). Shredders and riparian vegetation. BioScience, 39: 24-30.

Dangles, O. \& Malmqvist, B. (2004). Species richnessdecomposition relationships depend on species dominance. Ecology Letters, 7: 395-402.

Dethier, V. G. (1959). Food-plant distribution and density and larval dispersal as factors affecting insect populations. Canadian Entomologist, 91: 581-596.

Dhandapani, N., Jayaraj, S. \& Rabindra, R. J. (1993). Cannibalism on nuclear polyhedrosis virus infected larvae by Heliothis armigera (Hubn.) and its effect on viral infection. Insect Science and Its Application, 14: 427-430.

Dobson, M., Magana, A., Mathooko, J. M. \& Ndegwa, F. K. (2002). Detritivores in Kenyan highland streams: more evidence for the paucity of shredders in the tropics. Freshwater Biology, 47: 909-919.

Domínguez, E. \& Fernándezm H. (2009). Macroinvertebrados bentónicos sudamericanos: sistemática y biología. Fundación Miguel Lillo: Argentina.

Downes, B. J., Lake, P. S. \& Schreiber, E. S. G. (1993). Spatial variation in the distribution of stream invertebrates: implications of patchiness for models of community organization. Freshwater Biology, 30: 119-132. 
Dudgeon, D. (1994). The influence of riparian vegetation on macroinvertebrate community structure and functional organization in six New Guinea streams. Hydrobiología, 294: 65-85.

Eaton, A. D., Clesceri L. S. \& Greenberg, A. E. (1995). (Eds.) Standard Methods for the Examination of Water and Wastewater, $19^{\text {th }}$ edition. American Public Health Association: Washington, D. C.

Elliott, J. M. (1973). Some Methods for the Statistical Analysis of Samples of Benthic Invertebrates. Scientific Publication No. 25, Freshwater Biological Association. Ambleside, Westmorland, England.

Fossati, O., Vallier, P. \& Mosseron M. (1998). Macroinvertebrates assemblages in rivers of Nuku-Hiva, French Polynesia, before and after antisimuliid treatments. Archiv für Hydrobiologie, 142: 229-240.

Fossati, O., Mosseron, M. \& Keith, P. (2002). Distribution and habitat utilization in two atyid shrimps (Crustacea: Decapoda) in rivers of Nuku-Hiva Island (French Polynesia). Hydrobiología, 472: 197-206.

Gómez-Aguirre, A. M., Longo-Sánchez, M. \& Blanco, J. F. (2009). Macroinvertebrate assemblages in Gorgona Island streams: spatial patterns during two contrasting hydrologic periods. Actualidades Biológicas, 31: 161-178.

Graça, M. A. S., Cressa, C., Gessner, M. O., Feio, M. J., Callies, K. A. \& Barrios, C. (2001). Food quality, feeding preferences, survival and growth of shredders from temperate and tropical streams. Freshwater Biology, 46: 947-957.

Greig-Smith, P. (1983). Quantitative Plant Ecology. Blackwell. Oxford.

Hansen, R. A. (2000). Effects of habitat complexity and composition on a diverse litter microarthropod assemblage. Ecology, 81: 1120-1132.

Hill, T. \& Lewicki, P. (2007). STATISTICA Methods and Applications. StatSoft, Tulsa.

Huryn, A. D. \& Benke, A. C. (2007). Relationship between biomass turnover and body size for stream communities. In A. Hildrew, D. Raffaelli \& R. EdmondsBrown (Eds.), Body size: The structure and function of aquatic ecosystems (pp. 55-76). Cambridge University Press, New York, USA.

Iwao, S. (1979). The method for analyzing the distribution patterns of single and mixed species populations. In G. P. Patil \& M. L. Rosenzweig (Eds.), Contemporary Quantitative Ecology and Related Ecometrics (pp. 215-228). International Co-operative Publishing House, Fairland.

Lamprecht, H. (1962). Ensayo sobre métodos para análisis estructural de los bosques tropicales. Acta Científica Venezolana, 13: 65.
Lavelle, P., Lattaud, C., Trigo, D. \& Barois, I. (1994). Mutualism and biodiversity in soils. Plant Soil, 170: 23-33.

Li, A. O. Y. \& Dudgeon, D. (2008). Food resources of shredders and other benthic macroinvertebrates across a range of shading conditions in tropical Hong Kong streams. Freshwater Biology, 53: 2011-2025.

Lloyd, M. (1967). Mean crowding. Journal of Animal Ecology, 36: 1-30.

Longo-Sánchez, M. \& Blanco, J. F. (2009). Sobre los filtros que determinan la distribución y la abundancia de los macroinvertebrados diádromos y no-díadromos en cada nivel jerárquico del paisaje fluvial en islas. Actualidades Biológicas, 31: 179-195.

Longo-Sánchez, M., Gómez-Aguirre, A. M., Blanco J. F. \& Zamora-González, H. (2009). Cambios multianuales y espaciales de la composición y estructura del ensamble de insectos acuáticos en las quebradas perennes de la Isla Gorgona, Colombia. Actualidades Biológicas, 31: 141-160.

Ludwing, J. A. \& Reynolds, J. F. (1988). Statistical Ecology: a primer on methods and computing. WileyInterscience publication. USA.

March, J. G., Benstead, J. P., Pringle, C. M. \& Ruebel, M. W. (2001). Linking shrimp assemblages with rates of detrital processing along an elevational gradient in a tropical stream. Canadian Journal of Fisheries and Aquatic Sciences, 58: 470-478.

March, J. G., Benstead, J. P., Pringle, C. M. \& Luckymis, M. (2003). Benthic community structure and invertebrate drift in a Pacific Island stream, Kosrae, Micronesia. Biotropica, 35: 125-130.

Marquet, G. (1991). Freshwater crustaceans of French Polynesia: taxonomy, distribution and biomass (Decapoda). Crustaceana, 61: 125-140.

Mcaleece, N., Lambshead, P. J. D. \& Paterson, G. L. J. (1997). Biodiversity Pro. Statistics analysis software. London, England.

Morisita, M. (1971). Composition of the ID-index. Researches on Population Ecology, 13: 1-27.

Moulton, T. P., Souza, M. L., Silveira, R. M. L. \& Krsulovic, F. A. M. (2004). Effects of ephemeropterans and shrimps on periphyton and sediments in a coastal stream (Atlantic forest, Rio de Janeiro, Brazil). Journal of the North American Benthological Society, 23: 868-881.

Myers, J. H. (1978). Selecting a measure of dispersion. Environmental Entomology, 7: 619-621.

Myers, N., Mittermeier, R. A., Mittermeier, C. G., Da Fonseca, G. A. B. \& Kent, J. (2000). Biodiversity hotspots for conservation priorities. Nature, 403: 853-858. 
Peckarsky, B. L. (1980). Influence of detritus upon colonization of stream invertebrates. Canadian Journal of Fisheries and Aquatic Sciences, 37: 957-963.

Peckarsky, B. L. (1996). Predator-prey interactions. In F. R. Hauer \& G. A. Lamberti (Eds.), Methods in Stream Ecology (pp. 431-451). Academic Press, California, USA.

Petitt, F. L. \& Wietlisbach, D. O. (1992). Intraspecific com-petition among same-aged larvae of Liriomyza sativae (Diptera: Agromyzidae) in lima bean primary leaves. Environmental Entomology, 21: 136-140.

Petraitis, P. S. (1979). Likelihood measures of niche breadth and overlap. Ecology, 60: 703-710.

Poff, N. L. R, Palmer, M. A., Angermeier, P. L., Vadas, R. L., Hakenkamp, C. C. Bely, A., Arensburger, P. \& Martin, A. P. (1993). Size structure of the metazoan community in a Piedmont stream. Oecología, 95: 202-209.

Pringle, C. M., Naiman, R. J., Bretschko, G., Karr, J. R., Oswood, M. W., Webster, J. R., Welcomme, R. L. \& Winterbourn, M. J. (1988). Patch dynamics in lotic systems: the stream as a mosaic. Journal of the North American Benthological Society, 7: 503-524.

Rabinovich, J. E. (1982). Introducción a la ecología de poblaciones animales. CECSA. México.

Ramírez, A. \& Pringle, C. M. (1998). Structure and production of a benthic insect assemblage in a neotropical stream. Journal of the North American Benthological Society, 17: 443-463.

Ramírez, A. \& Hernández-Cruz, L. R. (2004). Aquatic insect assemblages in shrimp-dominated tropical streams, Puerto Rico. Biotropica, 36: 259-266.

Rangel, O. (1990). Tipos de vegetación. In J. Aguirre \& O. Rangel (Eds.), Biota y Ecosistemas de Gorgona (pp. 109-126). Fondo para la protección del medio ambiente-FEN. Bogotá, Colombia.

Rangel, O. \& Arellano, H. (2004). Clima del Chocó Biogeográfico de Colombia. In J. O. Rangel (Ed.), Diversidad biótica IV: El Chocó biogeográfico/Costa Pacificia (pp. 39-82). Instituto de Ciencias Naturales, Universidad Nacional de Colombia, Bogotá, Colombia.

Resh, V. H., Barnes, J. R. \& Craig, D. A. (1990). Distribution and ecology of benthic macroinvertebrates in the Opunohu River catchment, Moorea, French Polynesia. Annals de Limnologie, 26: 195-214.

Ríos, B. T., Encalada, A. E. \& Prat, N. F. (2009). Leaf litter dynamics and its use by invertebrates in a highaltitude tropical Andean stream. International Review of Hydrobiology, 94: 357-371.

Roldán, G. (1988). Guía para el estudio de los macroinvertebrados acuáticos del Departamento de Antioquia. Fondo FEN-COLCIENCIAS. Bogotá, Colombia
Rueda-Delgado, G., Wantzen, K. M. \& Tolosa, M. B. (2006). Leaf-litter decomposition in an Amazonian floodplain stream: effects of seasonal hydrological changes. Journal of the North American Benthological Society, 25: 233-249.

Schlegel, D. \& Bauer, T. (1994). Capture of prey by two pseudoscorpion species. Pedobiología 38: 361-373.

Shaukat, S. S. \& Siddiqui, I. A. (2004). Spatial pattern analysis of seeds of an arable soil seed bankand its relationship with above-ground vegetation in an arid region. Journal of Arid Environments, 57: 311-327.

Smith, G. C., Covich, A. P. \& Brasher, A. M. D. (2003). An ecological perspective on the biodiversity of tropical island streams. BioScience, 53: 1048-1051.

Souza, M. L. \& Moulton, T. P. (2005). The effects of shrimps on benthic material in a Brazilian island stream. Freshwater Biology, 50: 592-602.

Swan, C. M. \& Palmer, M. A. (2004). Leaf diversity alters litter breakdown in a Piedmont stream. Journal of the North American Benthological Society, 23: 15-28.

Taylor, L. R. (1984). Assessing and interpreting the spatial distribution of populations. Annual Review of Entomology, 29: 321-357.

Tomanova, S., Goitia, E. \& Helešic, J. (2006). Trophic levels and functional feeding groups of macroinvertebrates in neotropical streams. Hydrobiología, 556: 251-264.

Townsend, C. R. \& Thompson, R. M. (2007). Body size in streams: macroinvertebrate community size composition along natural and human-induced environmental gradients. In A. Hildrew, D. Raffaelli \& R. EdmondsBrown (Eds.). Body size: The structure and function of aquatic ecosystems (pp. 77-97). Cambridge University Press, New York, USA.

Turner, D., Williams, D. D. \& Alkins-Koo, M. (2008). Longitudinal changes in benthic community composition in four neotropical streams. Caribbean Journal of Science, 44: 380-394.

Valencia, S. M., Pérez, G. A., Lizarazo, P. X. \& Blanco, J. F. (2009). Patrones espacio-temporales de la estructura y composición de la hojarasca en las quebradas del Parque Nacional Natural Gorgona. Actualidades Biológicas, 31: 197-211.

Vannote, R. L., Minshall, G. W., Cummins, K. W., Sedell, J. R. \& Cushing, C. E. (1980). The River Continuum Concept. Canadian Journal of Fisheries and Aquatic Sciences, 37: 130-137.

Wantzen, K. M. \& Wagner, R. (2006). Detritus processing by invertebrate shredders: a neotropical-temperate comparison. Journal of the North American Benthological Society, 25: 216-232.

Wantzen, K. M., Yule, C. M., Mathooko, J. M. \& Prigle, C. M. (2008). Organic matter processing in tropical streams. In D. Dudgeon (Ed.), Tropical 
Stream Ecology (p. 44-65.). Academic Press, London, England.

Wardle, D. A., Bonner, K. I. \& Nicholson, K. S. (1997). Biodiversity and plant litter: experimental evidence which does not support the view that enhanced species richness improves ecosystem function. Oikos, 79: 247-258.

Wiggins, G. B. (1996). Larvae of the North American caddisfly genera (Trichoptera), Second edition. University of Toronto Press. Toronto, Canada.

Yam, R. S. W. \& Dudgeon, D. (2005). Stable isotope investigation of food use by Caridina spp. (Decapoda:Atyidae) in Hong Kong streams. Journal of the North American Benthological Society, 24: 68-81.
Yule, C. M. (1996a). Trophic relationships of the benthic invertebrate fauna of an aseasonal tropical stream on Bougainville Island, Papua New Guinea. Journal of Tropical Ecology, 12: 517-534.

Yule, C. M. (1996b). Spatial distribution of the invertebrate fauna of an aseasonal tropical stream on Bougainville Island, Papua New Guinea. Archiv für Hydrobiology, 137: 227-249.

Yule, C. M., Leong, M. Y., Liew, K. C., Ratnarajah, L., Schmidt, K., Wong, H. M., Pearson, R. G. \& Boyero, L. (2009). Shredders in Malaysia: abundance and richness are higher in cool upland tropical streams. Journal of the North American Benthological Society, 28: 404-415. 
